\title{
Türkiye'de Hayvan Varlığının Mevcut ve Gelecekteki Durumu; TR83 Bölgesi Açılımı
}

\author{
Gülistan Erdal $^{1 *}$, Hilmi Erdal ${ }^{2}$, Hatice Yavuz $^{1}$, Ali Çallı ${ }^{1}$ \\ ${ }^{\text {I} G a z i o s m a n p a s ̧ a ~ U ̈ n i v e r s i t e s i, ~ Z i r a a t ~ F a k u ̈ l t e s i, ~ T a r ı m ~ E k o n o m i s i ~ B o ̈ l u ̈ m u ̈, ~} 60240$ Tokat, Türkiye \\ ${ }^{2}$ Gaziosmanpaşa Üniversitesi, Sosyal Bilimler MYO, Yönetim ve Organizasyon Bölümü,60240 Tokat, Türkiye \\ M A K A L E B İ L G İ S İ \\ Ö Z E T
}

Geliş 29 Nisan 2016

Kabul 01 Ağustos 2016

Çevrimiçi baskı, ISSN: 2148-127X

Anahtar Kelimeler:

Türkiye de hayvancılık

TR83 Bölgesi

Hayvan varlığ

Hayvancılık desteklemeleri

Tarımsal destekler

*Sorumlu Yazar:

E-mail: gulistan.erdal@gop.edu.tr
Bu çalışmada Türkiye genelinde ve TR83(Amasya, Çorum, Samsun, Tokat) bölgesinde büyükbaş ve küçükbaş hayvan varlığı incelenmiștir. Türkiye ve TR83 bölgesinde bulunan büyükbaş ve küçükbaş hayvan varlığını ait 1996-2014 değerleri kullanılarak trend analizi yapılmış ve 2020 yılı tahmini değerleri belirlenmiştir. Çalışmada 2020 yılına ait yapılan projeksiyonlarda yerli sı̆̆ır ırkının Türkiye genelinde azalmaya devam edeceği görülmektedir. Buna karşın TR83 bölgesinde yerli sığır ırkının artacağı tahmin edilmiştir. Yine araştırmada incelenen tüm hayvan varlıklarının 2020 yılına kadar geçen zamanda artış kaydedeceği tahmin edilmiştir. Kuşkusuz bu artışta Türkiye de uygulanan hayvancilık destekleme politikalarının etkisi yadsınamaz. $\mathrm{Bu}$ anlamda mevcut hayvancılık destekleme politikalarının sektöre katkısının ve etkinliğinin saptanması ve aksayan yönlerinin incelenmesi, daha doğru ve etkin politikaların belirlenmesi açısından önemlidir.

Turkish Journal Of Agriculture - Food Science And Technology, 4(8): 668-675, 2016

\section{The Present and Future Statues of Animal Presence in Turkey; The Declination of TR83 Area}

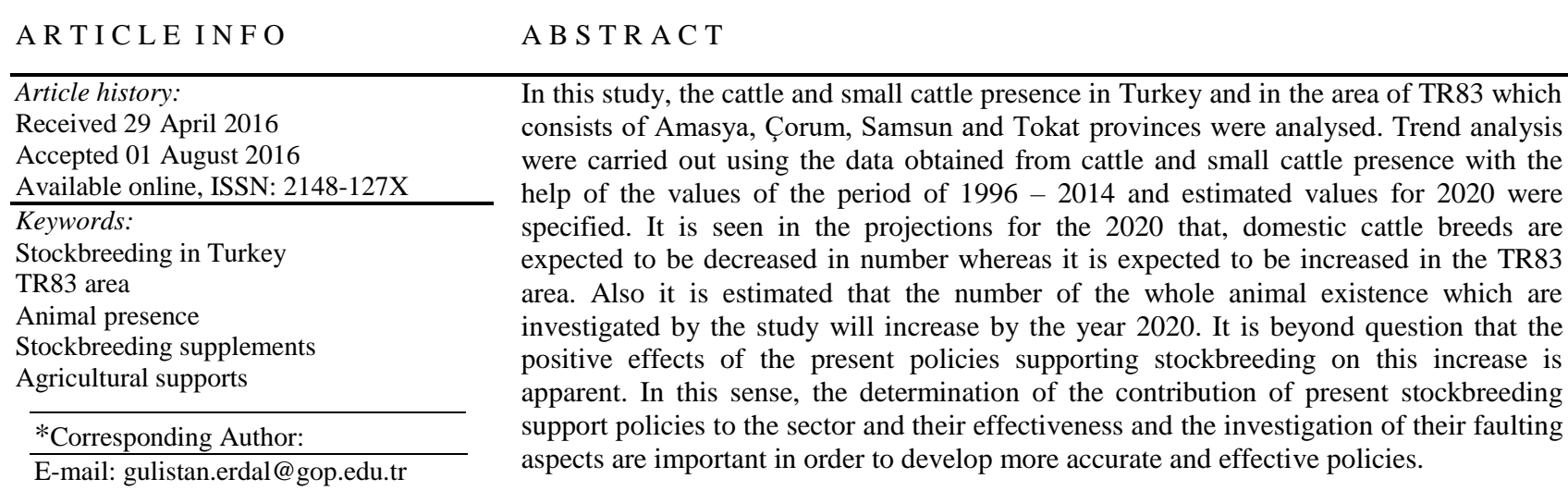

\section{Giriş}

Tarım sektörü; nüfus, işgücü-istihdam, beslenme, tarımsal üretim, tarımsal ürünlerin yurt içi tüketimi, sanayiye girdi sağlaması ve sanayide üretilen ürünlere pazar oluşturması, milli gelir ve ödemeler dengesi açısından Türkiye ekonomisinde önemli bir konuma sahiptir (Erkuş ve ark., 1995).

Tarımsal faaliyet bitkisel ve hayvansal üretimi ile bunların değerlendirilmesini kapsayan bir bütündür. Bu kapsamda hayvansal üretim faaliyetleri; iş verimliliğinin artırılması, işgücünün dengeli kullanımı, toprak verimliliğinin muhafazası ve işletmede gıda maddesi niteliğinde olmayan ve endüstride hammadde olarak kullanılmayan tarımsal ürünleri değerlendirerek kaynak israfina engel olması açısından önem kazanmaktadır. Ayrıca tarım işletmelerinde likiditenin sağlanmasının ve riskin azaltılmasının hayvansal üretim faaliyetlerine yer verilmesini zorunlu hale getirdiği ifade edilmektedir (Topçu, 2004).

Hayvansal üretim içerisinde özellikle bölgeler arası dengeli kalkınmanın gerçekleştirilmesinde, iç ve dış pazarların besili karkas ağırlığına sahip ve kaliteli sığır eti taleplerinin karşılanması açısından besiciliğin de önemi 
büyüktür (Akçay, 2006). Bundan dolayı, tarım işletmelerinin çoğu belirli miktar da hayvana sahip olmaktadir.

Hayvancık, bağlı diğer alanlarda da istihdam olanaklarının genişlemesi ve süreklilik arz etmesi açısında önemli bir tarımsal faaliyettir. Hayvancılık alanından elde edilen gelirin diğer sektörler için yeni bir gelir kaynağ olacağ1 düşünüldügünde, ülke ekonomisi için hayvancılığın taşıdığı önem daha net görülmektedir (Sapan ve Etiler, 2004; Eren, 2006). Türkiye doğal yapısı ve ekolojik şartları açısından hayvancılığa elverişli kabul edilmesine rağmen, uzun dönemler boyunca hayvansal üretimin, düşük verimli yerli 1 rk hayvanlarla yapılıyor olmasından dolayı yeterli düzeye ulaştırılamadığ söylenebilir (Özkan ve Erkuş, 2003; Vural ve Fidan, 2007).

Tarım sektöründe gelişme göstermiş olan ülkelerin çoğunda hayvancılığın tarımsal üretim içerisindeki payı \%50'nin üzerindedir (Aydemir ve Pıçak, 2007). Türkiye'de ise toplam tarımsal üretim içeresin de hayvansal üretimin payı $\% 30$ civarındadır. Konuya işletmecilik açısından bakıldığında Türkiye'de yaklaşık 3 milyon tarım işletmesi bulunmakta ve bu işletmelerin $\% 2,36$ 'sında yalnızca hayvancilık yapılmakta, $\% 67,43$ 'ünde ise bitkisel ve hayvansal üretim birlikte gerçekleştirilmektedir (Anonim, 2014a).

$\mathrm{Bu}$ çalışmada Türkiye ve TR83(Amasya, Çorum, Samsun, Tokat) bölgesinde büyükbaş ve küçükbaş hayvan varlığı incelenmiş, geleceğe yönelik projeksiyonlar yapılarak konu değerlendirilmiştir.

Konu, Türkiye bölge ve iller düzeyinde ayrıntılı olarak ele alınmıştır. Araştırma, daha önce yapılmış benzer çalışmalar ile desteklenmiştir (Aydemir ve P1çak, 2007; Demir ve Yavuz, 2010; Sapan ve Etiler, 2004; Vural ve Fidan, 2007).

\section{Materyal ve Yöntem}

Çalışmada Türkiye de, TR83 Bölgesinde, Tokat, Samsun, Çorum ve Amasya illerinde bulunan büyükbaş ve küçükbaş hayvan varlığını 1996-2014 yılları arasında incelenmiştir. Veriler Türkiye İstatistik Kurumu resmi internet sitesinden elde edilmiştir (TÜİK, 2015).

Çalışmada, tüm alanlardaki hayvan sayısındaki değişimler grafikler ile özetlenmiştir. Yine tüm alanlara ait hayvan sayıları için trend analizleri uygulanmış ve 2020 yılı hayvan varlıkları tahmin edilmiştir. Trend Analizi, zaman serileri analizi yöntemlerinden biridir. Trend, bir zaman serisinin uzun dönemde belirli bir yöne doğru gösterdiği gelişmedir. Trend analizi, verilerde yer alan değerlerin zaman içerisinde gösterdikleri eğilimlerin incelenmesi ile yapılır. Trend analizi yapılırken, seçilen y1lı izleyen yıllardaki veri değerlerinin bu yıla göre göstermiş oldukları eğilimler dikkate alınır (Yüzer ve ark., 2006).

Araştırmada trend analizleri için MINITAB 16 istatistik paket programı kullanılmıştır (Minitab, 2007). Analizlerde, Quadratic (2. Derece), Linear (Doğrusal), Exponential (Ussel) ve S-Curve (S-Eğrisi) alternatif trend modelleri denenmiştir. 1996-2014 yılları için yapılan trend analizlerinden elde edilen sonuçların doğruluk ölçütleri olarak Ortalama Mutlak Yüzde Hata (MAPE,
Mean Absolute Percentage Error), Ortalama Mutlak Sapma (MAD, Mean Absolute Deviation), ve Ortalama Karesel Sapma (MSD, Mean Squared Deviation) ölçütleri kullanılmıştır. Trend analizleri doğruluk ölçütü sonuçlarına göre, Quadratic Trend Modelinin uygun olduğuna karar verilmiştir.

\section{Türkiye'de Hayvancılık}

Türkiye'nin coğrafi özellikleri bakımından her türlü hayvan yetiştiriciliği için uygun ortam ve potansiyele sahip olduğu söylenebilir. Türkiye'de 1970'li yıllara kadar hem büyükbaş hem de küçükbaş hayvan yetiştiriciliğinin tamamına yakını, yerli ırk hayvanlarla ve doğal otlaklarda yapılan mera hayvancılığı şeklinde sürdürülmüştür.

Türkiye'de hayvancılık, 1923 yılından günümüze kadar çeşitli destekleme politikaları ile desteklenmiştir. Yapılan desteklemeler 1950'li yıllara kadar yerli ırkların 1slahı, hastalıkların kontrolü ve veterinerlik hizmetleri üzerine yoğunlaşmıştır. Daha sonraki yıllarda Et Balık Kurumu, Türkiye Süt Endüstrisi Kurumu ve Yem Sanayi gibi Kamu İktisadi Teşebbüsleri aracılığı ile girdi ve ürüne yönelik desteklemeler şeklinde devam etmiştir. $\mathrm{Bu}$ destekler 1963 yılında başlayan planlı dönemle birlikte ivme kazanmıştır (Demir, 2009). Türkiye Süt Endüstrisi Kurumu ve Yem Sanayinin 1995 yilında tamamen özelleştirilmesi ile süt alımı ve yem desteği kaldırılmıştır.

2000 yılında yayınlanan 467 Sayılı Hayvancılığın Desteklenmesi Hakkında Bakanlar Kurulu Kararı ile hayvancılık destekleme politikaları yeniden düzenlenmiştir. $\mathrm{Bu}$ düzenlemeler, takip eden yıllarda alınan yeni kararlarla devam etmiştir. 2006 yılında yeniden düzenlenen 10811 sayılı karara göre, hayvancılık faaliyetlerinde ırk 1slahı, kaba yem üretiminin artırılması, verimliliğin artırılması, işletmelerin ihtisaslaşması, işletmelerde hijyen şartlarının sağlanması, hayvan sağlığ ve refahı, hayvan kimlik sisteminin teşviki, hayvansal ürünlerin işlenmesi ve pazarlanması ile bunlarla ilgili kontrol, takip ve standartların iyileştirilmesi amacıyla mevcut destekleme araçlarına ek olarak et primleri, pazarlama destekleri, hayvancılık işletmelerinin modernizasyonu destekleri ile çevresel önlemlere yönelik tedbirler uygulamaya konulmuştur (Demir, 2009).

$\mathrm{Bu}$ bağlamda Türkiye'de hayvancilık destekleme ödemelerinin payı 2002 yılında \%4' iken, 2010 y1lında \%22,3'e ve 2014 yılı için ise \%30'a çıkarılmıştır (Anonim,2015a).

Yukarıda da ifade edilmeye çalışıldığı üzere Türkiye'de genel bir ifadeyle 2000 y1lından önce hayvancılığa yönelik olarak geniş kapsamlı ve istikrarlı bir destekleme politikasından söz edilemezken 2000'li yıllarda daha sistemli ve artan oranlarda bir destekleme ödemesi gerçekleştirmektedir.

Tablo 1'de Türkiye'de 2014 y1lı itibariyle bazı hayvancılık destekleme konuları ve miktarları verilmiştir.

Tablo 1'de verilen desteklemeler dişında, suni tohumlama desteği, sürü yöneticisi istihdam desteği, besicilik materyal üretim desteği, süt primi desteği, yem bitkileri desteği, hayvan hastalıkları tazminatı, aşı desteği, su ürünleri, ipekböcekçiliği ve arı üretim desteği gibi birçok destekleme kalemi bulunmaktadır (Anonim, 2015b). 
Tablo 1 Türkiye'de bazı hayvancılık destekleme konuları ve miktarları

\begin{tabular}{|c|c|c|c|}
\hline \multicolumn{3}{|c|}{ Destekleme Konuları } & Birim Fiyat (2014) (TL/baş) \\
\hline \multirow{3}{*}{$\begin{array}{l}\text { Hayvan } \\
\text { Başı } \\
\text { Ödeme }\end{array}$} & $\begin{array}{l}\text { Sütçü ve kombine ırklar ve melezleri il } \\
\text { Etçi ırklar anaç sığır, } \\
\text { Anaç Manda } \\
\text { Sütçü ve kombine ırklar ve melezleri a }\end{array}$ & $\begin{array}{l}\text { kların melezleri anaç sığır } \\
\text { r soy kütüğü ilave }\end{array}$ & $\begin{array}{c}225 \\
350 \\
400 \\
70\end{array}$ \\
\hline & Besilik Materyal Üretim Desteği (baş) & $\begin{array}{l}\text { Anaç sı̆̆ır } \\
\text { Buzağı }\end{array}$ & $\begin{array}{l}350 \\
150\end{array}$ \\
\hline & $\begin{array}{l}\text { Anaç Koyun-Keçi } \\
\text { Islah Amaçlı Süt Kalitesinin Desteklen }\end{array}$ & ojesi & $\begin{array}{l}20 \\
50\end{array}$ \\
\hline
\end{tabular}

Kaynak: Anonim, 2015b

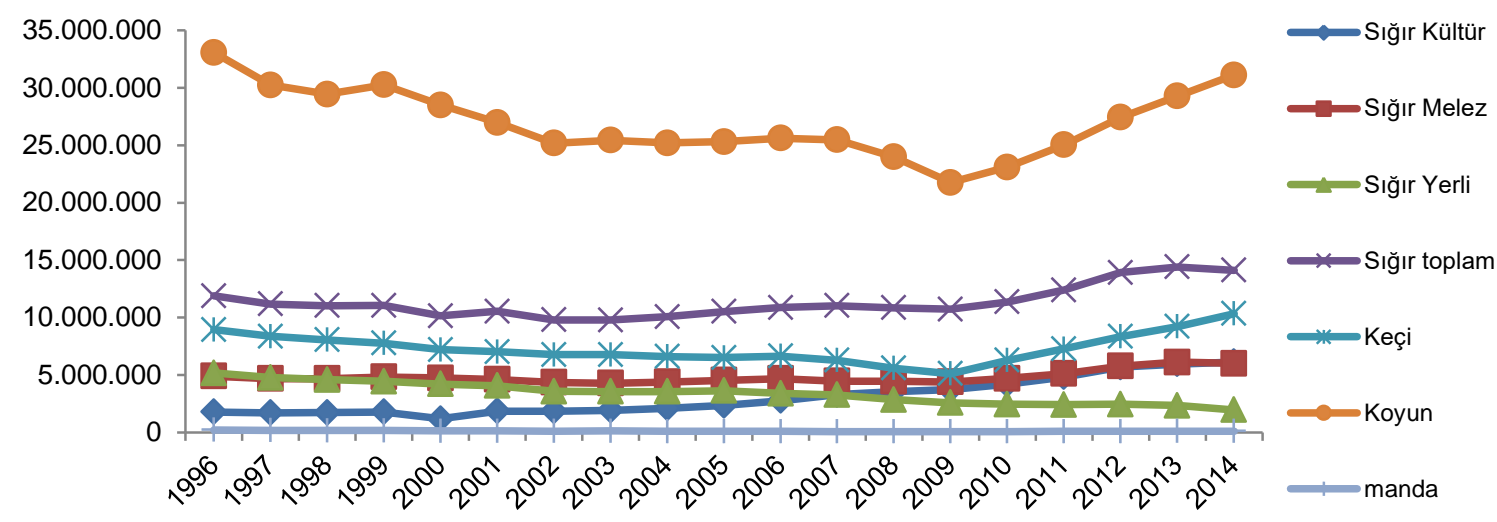

Grafik 1 Türkiye'de büyükbaş ve küçükbaş hayvan varlığ1

2000 y1lından itibaren ise yapılan devlet desteklemeleri ve teşvikler sayesinde büyük ölçekli hayvancılık tesis sayılarında önemli ölçüde artış olmuştur (TIGGEM,2013). Buna bağlı olarak hayvan varlığı da artış göstermiştir.

Grafik 1'de Türkiye deki 1996-2014 yılları arasındaki büyükbaş ve küçükbaş hayvan varlığı verilmiştir.

Grafik 1 incelendiğinde Türkiye de 1996-2014 yılları arasında her yıl koyun varlığının diğer hayvan varlıklarından daha fazla olduğu görülmektedir. Bu fazlalığa rağmen 1996 yılında 40 milyon olan koyun varlığı 2014 yılına gelindiğinde 31 milyona düşmüştür. Toplam sığır varlığının ise 1996-2014 yılları arasında 10 15 milyon arasında değiștiği görülmektedir. Diğer hayvan varlıkları da yıllara göre değişiklikler göstermektedir.

Çalışmada Türkiye'de bulunan hayvan varlıklarına ait 1996-2014 değerleri kullanılarak trend analizi yapılmış ve 2020 y1lı tahmini değerleri belirlenmiștir. Bulgulara ilişkin trend denklemleri ve mevcut değerler ile tahmini değerler arasında karşılaştırma yapılmış ve sonuçlar Tablo 2'de verilmiştir.

Tablo 2 incelendiğinde, Türkiye de 2004-2014 kültür sığırı varlığında \%160,72 bir artış olduğu görülürken, 2014-2020 yılları arasında da \%79,71'lik bir artış beklenmektedir. Toplam sığır üretiminde ise 2004-2014 yılları arasında \%34,17'lik bir artış varken, 2014-2020 yılları arasında bu artışın \%48,37'lik yükselmesi beklenmektedir. 2004-2014 yılları arasında hayvan varlıkları içerisinde sadece yerli sığır üretimin de azalış vardır ve bu azalışın 2014-2020 yıllarında da devam etmesi beklenmektedir. Bu durumun mevcut hayvancılık politikalarının bir etkisi olduğu söylenebilir. Manda varlığına bakıldığında ise 2004-2014 yılları arasında \%16,06'lık bir artış olduğu ve artışın 2014-2020 yılları arasında \%79,83'e ulaşması beklenmektedir.

\section{TR83 Bölgesinde Hayvancılık}

TR83 Bölgesi (Samsun, Tokat, Çorum, Amasya) tarımsal alan ve üretim bakımından oldukça zengindir. Bölgenin uygun iklim şartları ve zengin bitki örtüsü hayvancılık açısından büyük bir potansiyel oluşturmaktadır. Bölge, toplam sığır sayısı ve kültür melezi sığır sayısı yönünden Düzey 2 bölgeleri arasında ikinci ve yerli sığır sayısında üçüncü sırada yer almasına karşın, kültür ırkı sığır sayısı yönünden onuncu sırada yer almaktadır. Kültür sığır sayısının diğer bölgelere göre nispeten az olması bölgenin birim sığır başına verimlilik değerlerini düşürmektedir.

Samsun, toplam sığır sayısının en fazla olduğu ildir. Amasya ilinde Merkez, Suluova ve Gümüşhacıköy ilçelerinde; Çorum ilinde Merkez, İskilip ve Mecitözü ilçelerinde; Samsun ilinde Bafra, Çarşamba ve Vezirköprü ilçelerinde; Tokat ilinde ise Merkez, Zile ve Turhal ilçelerinde sığır sayısı oldukça fazladır (TİGEM, 2013).

Grafik 2'de TR83 Bölgesinde 1996-2014 y1lları arasındaki büyükbaş ve küçükbaş hayvan varlığ verilmiştir.

TR83 bölgesinde 1996-1999 yılları arasında koyun ve toplam sığır varlıkları birbirlerine yakın değerler gösterirken, 1999 yılından sonra toplam sığır varlığının koyun varlığına göre daha fazla arttığ görülmektedir.1996-2001 yılları arasında yerli sığır 
varlığı fazla iken 2006-2014 yılları arasında melez sığır varlığının artışı dikkat çekicidir. 1996 yılında yerli sığır varlığı yaklaşık 610 bin iken 2014 yılında 225 bin'e gerilemiştir (Grafik 2).
TR83 Bölgesinde bulunan hayvan varlıklarına ait trend analizi sonuçları ve karşılaştırmalı değerler Tablo 3'de sunulmuştur.

Tablo 2 Türkiye de hayvan varlığı ve geleceğe ait tahmini değerler

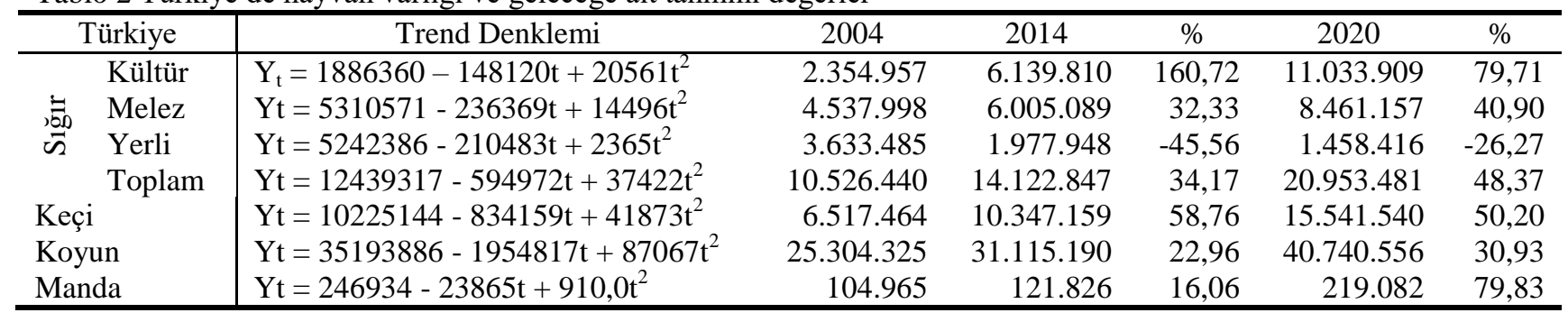

Tablo 3 TR83 bölgesinde hayvan varlığı ve geleceğe ait tahmini değerler

\begin{tabular}{|c|c|c|c|c|c|c|c|}
\hline & TR83 & Trend Denklemi & 2004 & 2014 & $\%$ & 2020 & $\%$ \\
\hline \multirow{4}{*}{$\begin{array}{l}\vec{D} \\
\overrightarrow{00} \\
\vec{\omega}\end{array}$} & Kültür & $\mathrm{Yt}=124141-13007 \mathrm{t}+1171,3 \mathrm{t}^{2}$ & 90.844 & 281.191 & 209,53 & 531.035 & 88,85 \\
\hline & Melez & $Y t=389010-6763 t+595 t^{2}$ & 362.225 & 457.863 & 26,40 & 591.514 & 29,19 \\
\hline & Yerli & $Y t=674444-47447 t+1266 t^{2}$ & 336.414 & 225.273 & $-33,04$ & 279.412 & 24,03 \\
\hline & Toplam & $Y t=1187596-67218 t+3032 t^{2}$ & 789.483 & 964.327 & 22,15 & 1.401 .957 & 45,38 \\
\hline \multicolumn{2}{|c|}{ Keci } & $Y t=178628-24272 t+1237 t^{2}$ & 62.917 & 186.144 & 195,86 & 345.142 & 85,42 \\
\hline \multicolumn{2}{|c|}{ Koyun } & $Y t=1310840-110014 t+4118 t^{2}$ & 622.823 & 740.663 & 18,92 & 1.134 .168 & 53,13 \\
\hline \multicolumn{2}{|c|}{ Manda } & $Y t=90915-10131 t+370,4 t^{2}$ & 31.200 & 31.616 & 1,33 & $69.124,30$ & 118,64 \\
\hline
\end{tabular}

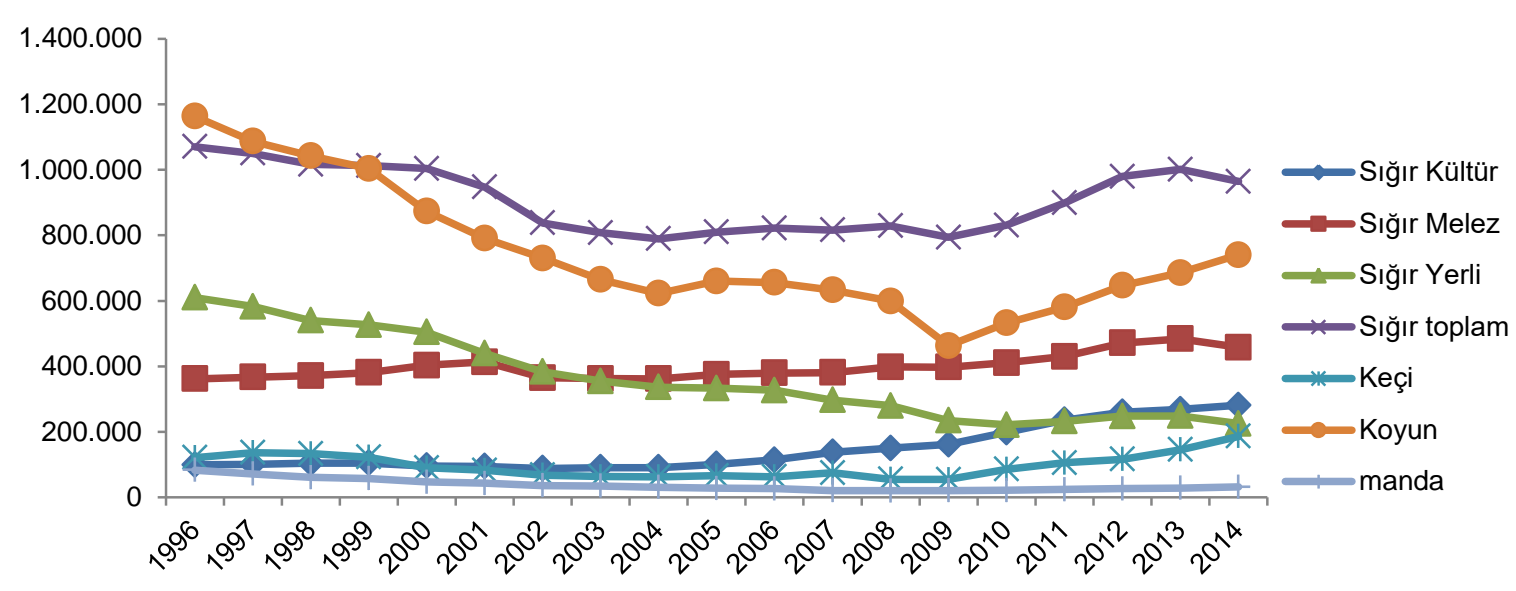

Grafik 2 TR83 bölgesinde büyükbaş ve küçükbaş hayvan varlığ1

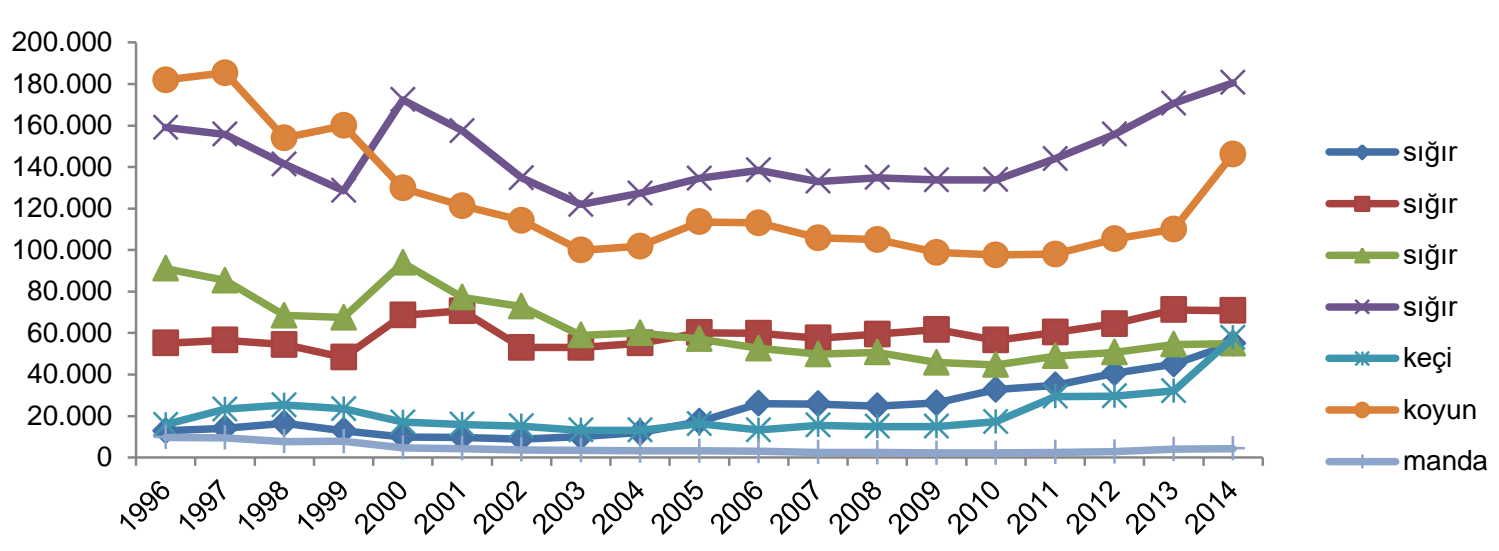

Grafik 3 Amasya ilinde büyükbaş ve küçükbaş hayvan varlığı 
Tablo 3'deki sonuçlara göre, 2004-2014 y1lları arasında hayvan varlığında en fazla artışın kültür sığırında olduğu görülmektedir (\%209,53). 2020 y1lında 2014 yılına göre \%118,64'lük bir oran ile en fazla artışın ise manda sayısında olması beklenmektedir. Diğer yandan 2004-2014 yılları arasında yerli sığır varlığında \%33,04'lük bir azalış olduğu görülürken, bu azalışın 2020 yılına gelindiğinde \%24,03'lük bir artışa dönüşmesi beklenmektedir. Her ne kadar ülke politikası olarak kültür sığır üretimi artırılmak istense de yerli sığır sayısında beklenen artış ve bölgenin Düzey 2 bölgeleri arasında yerli sığır sayısı bakımından üçüncü sırada yer alması gelenekçi bir yapının hakim olduğu anlamına gelebilir.

TR83 Bölgesinde yer alan illerden Amasya hayvancılık yönünden de önemli bir potansiyele sahiptir. İlde hayvancılık genelde aile işletmesi şeklindedir. Son yıllarda yapılan bazı çalışmalar ve destekler sonucu kültür hayvancılığında önemli ilerlemeler olmuştur. İlde hayvan ticaretinin de önemli bir yeri vardır. Ayrıca, süt ve besi amaçlı büyükbaş ve küçükbaş hayvancılık, Amasya ekonomisin de önemli bir yer tutmaktadır. Amasya ilinde hayvancılık büyükbaş hayvancılıkta işletme bazında yapılıp gelişmeye devam etmektedir.

Yerli ve melez hayvanları suni tohumlama yoluyla ıslah edilerek üstün vasıflı kültür ırkı hayvan elde etmek amacıyla yapılan suni tohumlama faaliyetleri de hızla devam etmektedir. İlde mera ıslah çalışmaları kapsamında yaklaşık 66 bin ha alan tespit edilmiş ve bunun 3 ha'lık kısmı tahdid ve tahsis edilmiştir. İlde ayrıca yem bitkileri üretiminin geliştirilmesine yönelik projeler yapılmaktadır (Anonim, 2016a).

Grafik 3'de 1996-2014 yılları arasında Amasya ili büyükbaş ve küçükbaş hayvan varlığ incelenmiştir.

Amasya ilinde 1996 - 2000 y1lları arasında koyun üretiminde azalmalar mevcut olduğu halde sayı olarak toplam sığır üretimlerinden fazla olduğu görülmektedir.
Daha sonraki yıllarda ise bu durumun kültür sığırı lehine değiştiği kaydedilmiştir. Diğer taraftan manda ve keçi sayısında da artışlar görülmektedir (Grafik 3).

Amasya ilindeki hayvan sayılarına ilişkin trend analizleri ve 2020 yılı tahmini değerleri Tablo 4'de sunulmuştur.

Amasya ili hayvan varlıkları trend analiz sonuçlarına göre 2020 yılında toplam sığır sayısında \%32,29'luk bir artış beklenmektedir. $\mathrm{Bu}$ artışın yoğun olarak kültür 1rkında gerçekleşeceği tespit edilmiştir (\%74). Zaten kültür sığır varlığı 2004-2014 yılları arasında en fazla artışın yaşandığı hayvan türü olarak dikkat çekmektedir (\%355). Koyun varlığında ise 2014 yılına göre 2020 yılında \%43'lük artış beklenmektedir. 2014-2020 yılları arasında en fazla artışın manda sayısında olduğu görülmektedir $(\% 138,64)$.

TR83 Bölgesi illerinden olan Çorum'un ekonomik yapısında, hayvancılık önemli bir yer işgal eder. Tarımla uğraşan hemen hemen her ailede hayvancilık yapilmaktadır (Anonim, 2011).

İlde 2000'li yılların başından itibaren damızlık, damızlık koyun ve keçi ve damızlık manda yetiştiricileri birlikleri kurulmuştur ve üye sayıları yaklaşık 5 bin civarında seyretmektedir. İlde hayvancılık yapan tarımsal amaçlı kooperatiflerin sayısı 30'un üzerindedir. Mevcut kooperatifler aracılığı ile çeşitli kültür ırkı hayvan alımları gerçekleştirilmektedir. Hayvanların besin kaynağının önemli bir kısmını oluşturan yem sektörü Çorum ili için oldukça genişlemiş bir potansiyel arz etmektedir. İlde entegre tesisler oluşumu için çalışmalar yapan büyük işletmeler de mevcuttur. Bunlardan başka ilde ayrıca mera 1slah çalışmaları ile 66 bin ha mera alanı tespit edilmiş ve bunun yaklaşı 18 bin ha'1 tahdit edilmiş 13 bin ha da tahsis edilmiştir (Anonim, 2016b). Tüm bu gelişmelerin hayvan varlığının artışında fazlaca etkili olduğu yadsinamaz.

Tablo 4 Amasya ilinde hayvan varlığ

\begin{tabular}{|c|c|c|c|c|c|c|}
\hline Amasya & Trend Denklemi & 2004 & 2014 & $\%$ & 2020 & $\%$ \\
\hline Kültür & $Y t=16545-2099 t+210,3 t^{2}$ & 12.069 & 54.902 & 354,90 & $95.508,70$ & 73,96 \\
\hline Melez & $Y t=58131-619 t+60,6 t^{2}$ & 55.162 & 70.764 & 28,28 & 80.502 & 13,76 \\
\hline Yerli & $Y t=96791-5693 t+173,1 t^{2}$ & 60.080 & 54.935 & $-8,56$ & $62.628,10$ & 14,00 \\
\hline Toplam & $\mathrm{Yt}=172014-8492 \mathrm{t}+447 \mathrm{t}^{2}$ & 127.311 & 180.601 & 41,86 & 238.922 & 32,29 \\
\hline Keçi & $Y t=31610-4646 t+277,5 t^{2}$ & 13.084 & 57.768 & 341,52 & $88.906,10$ & 53,90 \\
\hline Koyun & $Y t=205191-17238 t+695,8 t^{2}$ & 101.843 & 146.181 & 43,54 & 209.109 & 43,05 \\
\hline Manda & $Y t=11513-1436,3 t+55,55 t^{2}$ & 3.218 & 4.327 & 34,46 & $10.325,80$ & 138,64 \\
\hline
\end{tabular}

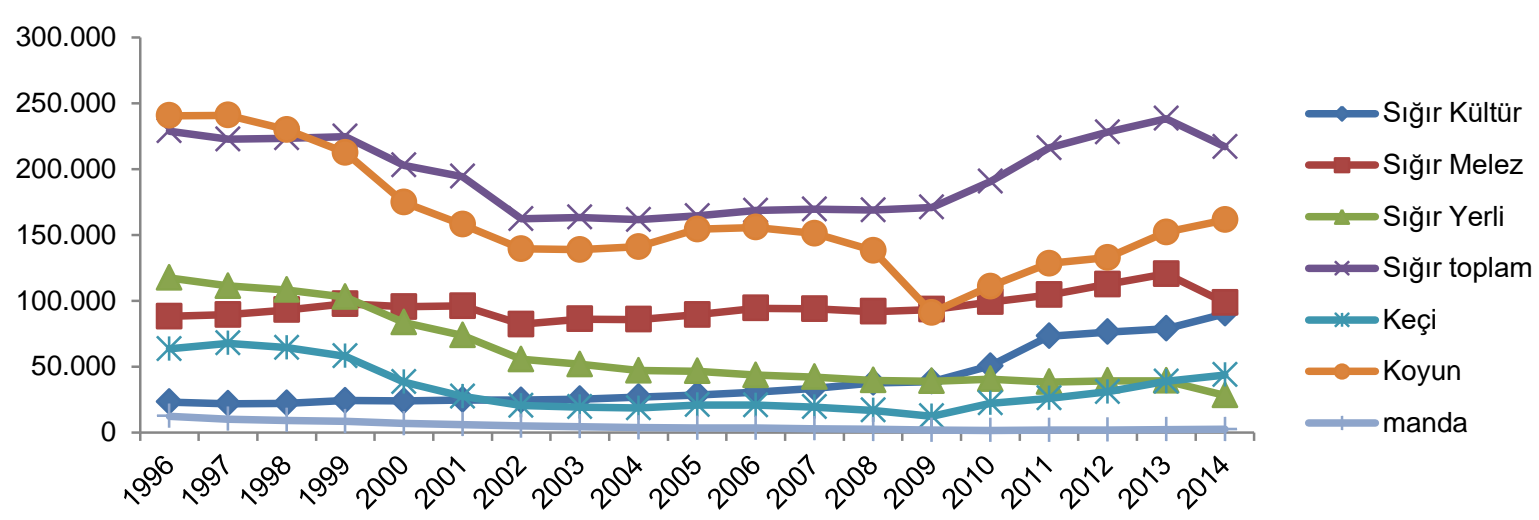

Grafik 4 Çorum ilinde büyükbaş ve küçükbaş hayvan varlığ 1 
Çorum ili 1996-2014 yıllarına ait büyükbaş ve küçükbaş hayvan varlığ 1 Grafik 4'de verilmiştir.

Grafik 4 incelendiğinde Çorum ilin de koyun sayısı 2014 yılında 1996 yılına göre \%67'lik bir düşüş göstermiştir. 1996 yıllında 228.700 olan toplam sığır sayısı ise 2014 yılında yaklaşık 217 bin civarında oluşmuştur. Yerli sığır ve manda hariç hemen hemen tüm hayvan varlıklarında 2009 yılına kadar süren düşme eğilimi sonraki yıllarda yerini artışa bırakmıştır. Bu artışta uygulanan hayvancılık destekleme politikalarının etkisi olduğu söylenebilir.

Çorum ilinde hayvan varlıklarına ait hesaplanan trend analiz sonuçlarına göre ise 2020 yılında diğer hayvan varlıkları ile birlikte koyun ve manda varlığında da artış yaşanacağ1 tahmin edilmiştir. Tahmin sonuçlarına göre, 2020 yılı yerli sığır varlığının 2014 yılına göre yaklaşık \%147 oranında, manda varlığının ise \%161 oranında artacağ1 söylenebilir.

TR83 Bölgesi illeri arasında yer alan Samsun ili sanayisindeki gelişmişlik yönünden dikkat çekmektedir. Hayvancılıkta da işletme bazında gelişmeler göstermektedir.

Samsun ilinin büyükşehir belediyesi olması nedeniyle büyükşehir yasasının tarım lehine getirdiği firsatları görmek mümkün olmaktadır. Bu bağlamda Büyükşehir Belediyesi Kırsal Kalkınma Daire Başkanlığı, ilçelerde tarım ve hayvancılığı geliştirmek, kalite ve verimi artırmak amacıyla Vezirköprü ve Havza ilçelerinde çiftçi ve hayvancılara karabuğday ve silajlık mısır tohumu yardımı yapmaktadır.

Samsun ili, yaklaşık 16 bin baş olan manda varlığ bakımından Türkiye'de birinci sırada yer almaktadır. Gıda Tarım ve Hayvancılık Bakanlığı'nın ilk kez 2008 yılında anaç mandaları destekleme kapsamına alması ile ilde manda yetiştiriciliği konusu daha da önem kazanmıştır. Bu anlamda Samsun ili damızlık manda yetiştiricileri birliği üye sayısını artırarak çalışmalarına devam etmektedir.

Samsun ili 1996-2014 yılları arasında büyükbaş ve küçükbaş hayvan varlığı incelenmiş değerler Grafik 5'de verilmiştir.

Samsun İlinde 1996- 2014 yılları arasında toplam sığır varlığında artış ve azalışlar olsa da diğer hayvan varlıklarından fazla olduğu görülmektedir. 1996 yıllında 359.080 olan toplam sığır varlığı 2014 yılında 309,199 gerilemiştir. Koyun varlığında ise 1996 yılında 336.350 olan sayı 2014 yılında 178.726 düşmüştür. Yerli sığır varlığ1 1996 yılında 173.310 iken 2014 y1lında 74.633'e gerilemiştir (Grafik 5).

Samsun ilinde bulunan hayvan varlıklarının geleceğe yönelik durumunu tahmin etmek amaciyla yapılan trend analizi sonuçlarına göre 2014-2020 yılları arasında en fazla artış kültür sığır ırkında beklenmektedir $(\% 106,48)$. Bunu \%80,33'lük bir artış ile manda varlığı takip etmektedir.

Samsun ilinde 2020 yılında toplam sığır varlığının 2014 y1lına göre \%41,49 artacağ 1 tahmin edilmektedir. Yerli sığır sayısında 2004-2014 yılları arasında \%31,33 bir düşüş görülürken, bu düşüşün 2014-2020 yılları arasında \%17,29 bir artışa dönüşmesi beklenmektedir.

TR83 Bölgesi illeri arasında yer alan Tokat'ta hayvancılık bitkisel üretimden hemen sonra gelir. Bölge zengin denilebilecek kadar hayvan varlığına sahip olup, süt hayvancılığını geliştirmek amacı ile her türlü ıslah çalışmaları yapılmaktadır. Montofon ırkının yanında Holstein rrkı ile kelkit vadisinde önemli miktarda Newjersy melezi yetiştirilmektedir. Koyunculukta "Karagül" koyunlarının yetiştirilmesi için üreticiler teşvik edilmektedir (Anonim, 2014b). Tokat iline ait 1996-2014 yılları arasında büyükbaş ve küçükbaş hayvan varlığı incelenmiş değerler Grafik 6'da verilmiştir.

Tokat İlinde 1996-2000 yılları arasında koyun varlığı fazla iken 2000 yılından sonra toplam sığır varlığı koyun varlığının önüne geçmiştir. 1996-2008 yılları arasında yerli sığır varlığı fazla iken 2008 yılından sonra melez sığır varlığı artış göstermiştir. Yerli sığır varlığında belirli bir azalış olup 1996 yılında 228.150 olan sayı 2014 yılında 67.428'e gerilemiştir. Melez sığır varlığı ise 1996 yılında 68.150 iken 2014 yılında 119.749'a yükselmiştir (Grafik 6).

Tokat ilinde bulunan hayvan varlıklarına 1996-2014 yıllarına ait veriler kullanılarak trend analizi yapılmış 2020 y1lı tahmini değerleri belirlenmiştir. Bu değerlere ilişkin veriler Tablo 7'de sunulmuştur.

Tablo 5 Çorum ilinde hayvan varlığ 1 ve geleceğe ait tahminler

\begin{tabular}{|c|c|c|c|c|c|c|c|}
\hline & Çorum & Trend Denklemi & 2004 & 2014 & $\%$ & 2020 & $\%$ \\
\hline \multirow{4}{*}{$\begin{array}{l}\stackrel{\overrightarrow{00}}{\vec{\omega}} \\
\overrightarrow{0}\end{array}$} & Kültür & $\mathrm{Yt}=30946-3947 \mathrm{t}+370,9 \mathrm{t}^{2}$ & 26.852 & 90.116 & 235,60 & 164.076 & 82,07 \\
\hline & Melez & $\mathrm{Yt}=95051-1811 \mathrm{t}+141,5 \mathrm{t}^{2}$ & 85.743 & 98.618 & 15,02 & 138.179 & 40,12 \\
\hline & Yerli & $Y t=135925-12866 t+408,7 t^{2}$ & 46.991 & 28.217 & $-39,95$ & $69.685,60$ & 146,96 \\
\hline & Toplam & $Y t=261745-18538 t+917 t^{2}$ & 161.590 & 216.951 & 34,26 & 371.195 & 71,10 \\
\hline \multicolumn{2}{|c|}{ Keçi } & $Y t=86396-12023 t+514,7 t^{2}$ & 18.525 & 43.690 & 135,84 & 107.540 & 146,14 \\
\hline \multicolumn{2}{|c|}{ Koyun } & $\mathrm{Yt}=274183-22174 \mathrm{t}+832 \mathrm{t}^{2}$ & 140.910 & 161.352 & 14,51 & 239.556 & 48,47 \\
\hline \multicolumn{2}{|c|}{ Manda } & $Y t=13278-1479,0 t+47,67 t^{2}$ & 3.625 & 2.333 & $-35,64$ & $6.097,46$ & 161,36 \\
\hline
\end{tabular}

Tablo 6 Samsun ilinde hayvan varlığı ve geleceğe ait tahminler

\begin{tabular}{|c|c|c|c|c|c|c|}
\hline Samsun & Trend Denklemi & 2004 & 2014 & $\%$ & 2020 & $\%$ \\
\hline Kültür & $Y t=38864-2654 t+261,5 t^{2}$ & 27.706 & 65.834 & 137,62 & 135.936 & 106,48 \\
\hline Melez & $Y t=160315-3872 t+240,8 t^{2}$ & 140.310 & 168.732 & 20,26 & 214.022 & 26,84 \\
\hline Yerli & $Y t=190536-11860 t+309,6 t^{2}$ & 108.691 & 74.633 & $-31,33$ & $87.534,40$ & 17,29 \\
\hline Toplam & $Y t=389715-18386 t+812 t^{2}$ & 276.707 & 309.199 & 11,74 & 437.492 & 41,49 \\
\hline Keçi & $Y t=22780-2547 t+127,6 t^{2}$ & 12.605 & 21.560 & 71,04 & $38.878,70$ & 80,33 \\
\hline Koyun & $Y t=382141-27882 t+878 t^{2}$ & 179.974 & 178.726 & $-0,69$ & 233.976 & 30,91 \\
\hline Manda & $Y t=36425-3896 t+149,2 t^{2}$ & 14.903 & 16.483 & 10,60 & $32.268,40$ & 95,77 \\
\hline
\end{tabular}




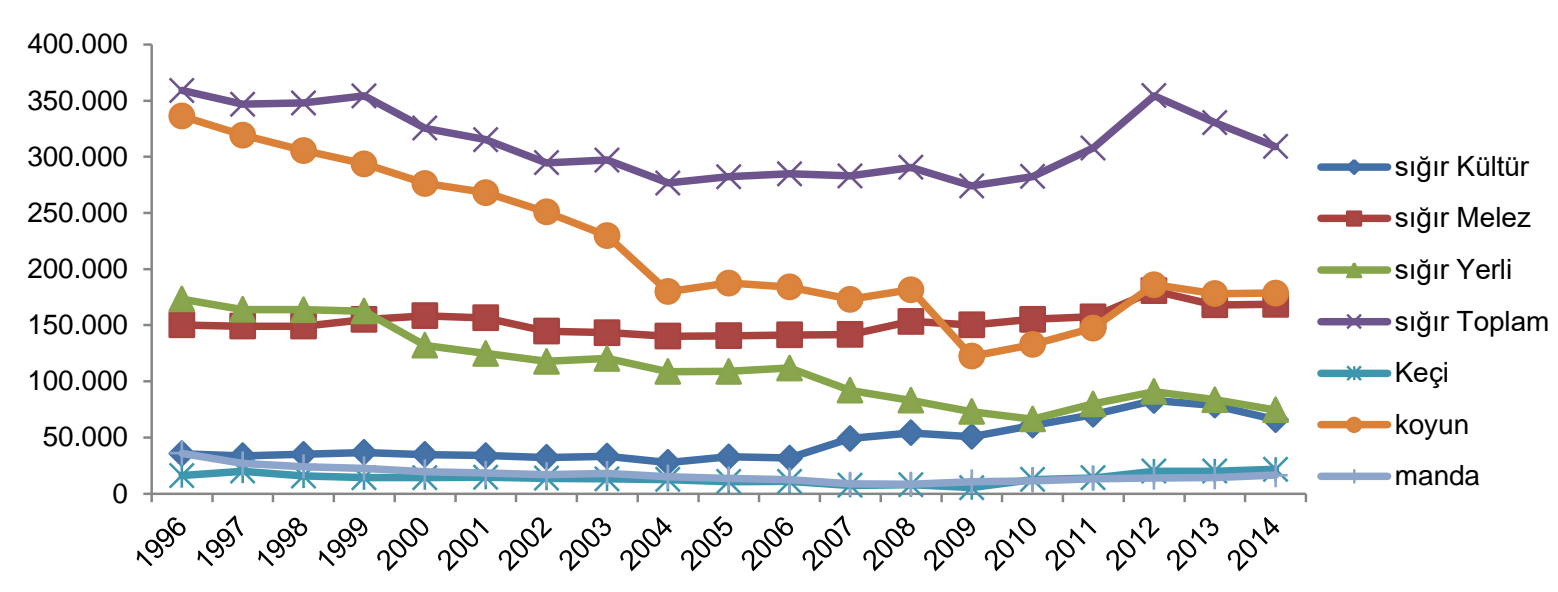

Grafik 5 Samsun ilinde büyükbaş ve küçükbaş hayvan varlığ 1

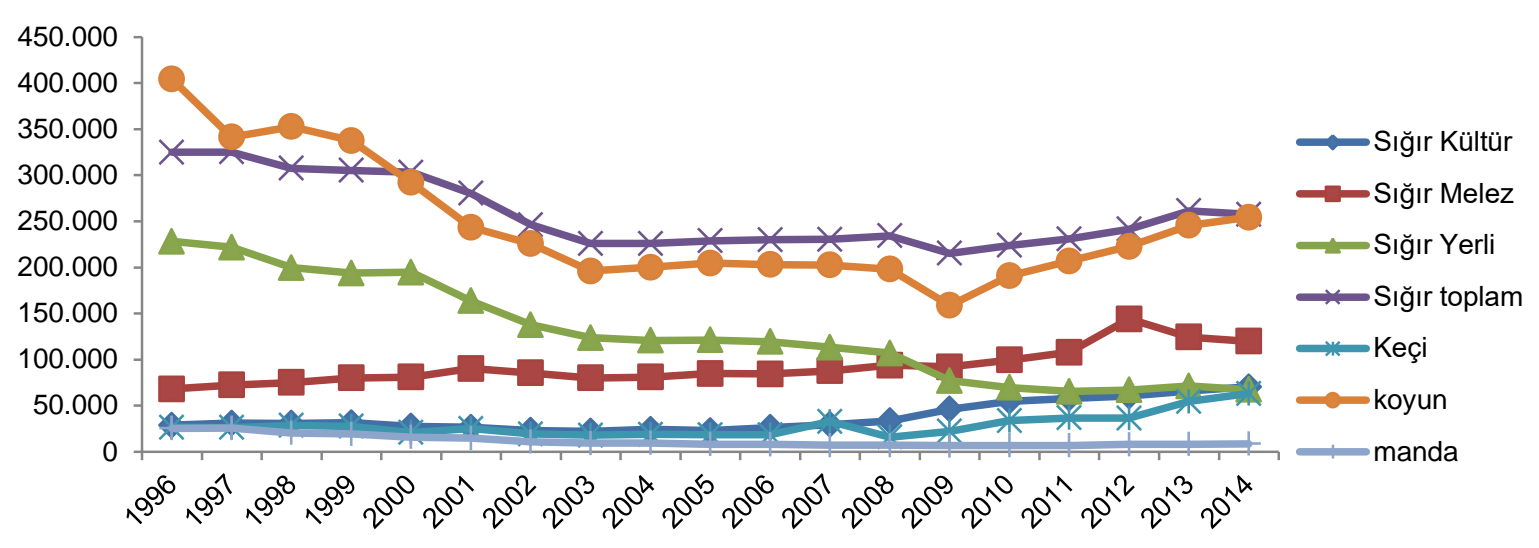

Grafik 6 Tokat ilinde küçükbaş ve büyükbaş hayvan varlığı

Tablo 7 Tokat ilinde hayvan varlığı ve geleceğe ait tahminler

\begin{tabular}{|c|c|c|c|c|c|c|c|}
\hline & Tokat & Trend Denklemi & 2004 & 2014 & $\%$ & 2020 & $\%$ \\
\hline \multirow{4}{*}{$\begin{array}{l}\overrightarrow{\bar{D}} \\
\vec{\omega}\end{array}$} & Kültür & $\mathrm{Yt}=38252-4394 \mathrm{t}+332,2 \mathrm{t}^{2}$ & 24.217 & 70.339 & 190,45 & 136.011 & 93,36 \\
\hline & Melez & $Y t=76380-942 t+194,0 t^{2}$ & 81.010 & 119.749 & 47,82 & 174.109 & 45,39 \\
\hline & Yerli & $Y t=251192-17028 t+374,5 t^{2}$ & 120.652 & 67.488 & $-44,06$ & $59.573,80$ & $-11,73$ \\
\hline & Toplam & $Y t=365535-21972 t+862 t^{2}$ & 225.879 & 257.576 & 14,03 & 354.678 & 37,70 \\
\hline \multicolumn{2}{|c|}{ Keçi } & $Y t=37872-5079 t+318,7 t^{2}$ & 18.703 & 63.126 & 237,52 & 110.064 & 74,36 \\
\hline \multicolumn{2}{|c|}{ Koyun } & $Y t=446003-41633 t+1667 t^{2}$ & 200.096 & 254.404 & 27,14 & 447.113 & 75,75 \\
\hline \multicolumn{2}{|c|}{ Manda } & $Y t=29699-3319 t+117,95 t^{2}$ & 9.454 & 8.473 & $-10,38$ & $20.432,70$ & 141,15 \\
\hline
\end{tabular}

Trend analizi sonuçlarına göre, Tokat ilinde 2004 yılından 2014 yılına kadarki süreçte görülen yerli sığır varlığındaki azalışın 2020 yılında da devam edeceği tespit edilmiştir (\%11,73). Yerli sığır varlığındaki azalışa karşın kültür $(\% 93,36)$ ve melez $(\% 45,39)$ sığıır varlığındaki artışın 2020 yılında da devam edeceği görülmektedir.

Diğer taraftan koyun ve keçi varlığında yaklaşık \%75'lık bir artış beklenmektedir. Toplam sığır varlığında 2004-2014 yılları arasında \%14,03'lük bir artış varken, bu artışın 2014-2020 yılları arasında \%37,70'e yükselmesi beklenmektedir. Tokat ili manda varlığında 2004-2014 yılları arasında \%10,38'lik düşme gerçekleşmiştir. Ancak 2020 yılında bu düşmenin yerini oldukça yüksek bir artış $(\% 141,15)$ alacağ 1 tahmin edilmiştir.

\section{Sonuç ve Öneriler}

$\mathrm{Bu}$ çalışmada Türkiye, TR83 (Amasya, Çorum, Samsun, Tokat) bölgesinde büyükbaş ve küçükbaş hayvan varlığg incelenmiştir. Çalışmada Türkiye de, TR83 Bölgesinde, Tokat Samsun, Çorum ve Amasya illerinde bulunan büyükbaş ve küçükbaş hayvan varlığg 1996-2014 yılları arasında tek tek değerlendirilmiştir. Araştırmada trend analizlerine yer verilerek 2020 yılındaki hayvan varlığ 1 tahmin edilmiştir.

Çalışmanın sonuçları bütün olarak değerlendirildiğinde, büyükbaş ve küçükbaş hayvan sayılarının yerli sı̆̆ır türü hariç diğer tüm türlerinde Türkiye'de genelinde, TR83 bölgesinde ve incelenen iller bazında yıllar itibariyle artış olduğu söylenebilir. 
Çalışmada 2020 yılına ait yapılan projeksiyonlarda yerli sığır ırkının Türkiye genelinde azalmaya devam edeceği fakat TR83 bölgesinde artacağı tahmin edilmiştir. Yine araştırmada incelenen tüm hayvan varlıklarının 2020 yılına kadar geçen zamanda artış kaydedeceği tahmin edilmiştir.

$\mathrm{Bu}$ çalışma elbette ki Türkiye'deki hayvancılık desteklerinin hayvan varlığı üzerindeki etkisini direkt inceleyen ve analiz eden bir çalışma değildir. Ancak çalışmada yapılan yüzde hesaplamaları ve trend analiz sonuçlarına göre hayvan sayılarında görülen artış eğiliminin destekleme verilen hayvan türlerinde daha yüksek olduğu söylenebilir. Yerli sığır varlığının Türkiye genelinde düşme eğiliminde olması bu 1rka destekleme yapılmamasından kaynaklanabilir. Fakat TR 83 bölgesinde yerli sığır varlığının korunduğu bunda da gelenekçi yapının kısa vadede de terkedilemediği anlamına geldiği söylenebilir. Bölgede özellikle küçük işletmelerin gelir faktörü nedeniyle yerli sığır yetiştiriciliğine devam ettiği göz ardı edilmemelidir.

Sonuç itibariyle, Türkiye'de 2004 yılından sonraki süreçte büyükbaş ve küçükbaş hayvan varlığının artış eğiliminde olduğu istatistiksel olarak tespit edilmiştir. Fakat mevcut artışın yeterli düzeyde olduğunu söylemek mümkün değildir. Bu anlamda sektörün desteklenmesi önem arz etmektedir. Diğer yandan amaç yalnızca hayvan sayısının artırılması değil, işletmelerin ihtisaslaşması, verimliliğin artırılması, hayvan sağlığı ve refahı, kaba yem üretiminin artırılması, işletmelerin modernizasyonu ve hijyen şartlarının sağlanması gibi konular için de büyük önem taşımaktadır. $\mathrm{Bu}$ anlamda mevcut hayvancılık destekleme politikalarının sektöre katkısının ve etkinliğinin saptanması ve aksayan yönlerinin belirlenmesi, daha doğru ve etkin politikaların belirlenmesi açısından önemlidir.

\section{Kaynaklar}

Akçay Y. 2006. Tokat-Turhal sığır besiciliği işletmelerinin yatırım analizi ve karlılığının belirlenmesi üzerine bir araştırma. Gaziosmanpaşa Üniversitesi Ziraat Fakültesi Yayınları No: 68, Araştırma Serisi No: 23, Tokat.

Anonim. 2011.TR83 Bölgesi Mevcut Durum Analizi, http://www.oka.org.tr/ [Erişim: 02/02/2016].

Anonim. 2014a. Sektör Raporu 2014,http://www.tuik.gov.tr/HbGetir.do?id=13512\&tb_id=1 [Erişim: 02/02/2016].
Anonim. 2014b. Tarım ve Hayvancilik, http://www.tokatdefterdarligi.gov.tr/ilimiz_ekonomi.html [Erişim: 04/03/2016].

Anonim. 2015a. Tarımsal Destekler, Gıda Tarım ve Hayvancılık Bakanlığı, Strateji Geliştirme Başkanlığı, http://www.tarim.gov.tr [Erişim: 04/03/2016].

Anonim. 2016a. İlimizde Hayvancilı̆̆ın Durumu, Amasya Valiliği, İl Gıda Tarım ve Hayvancılık Müdürlüğü http://www.amasyadsyb.org/docs/Semp_Amasya_Hayvancil ik_Durumu.pdf [Erişim: 04/03/2016].

Anonim. 2015b. Hayvancılık Genel Müdürlüğü 2015 Raporu, Gıda Tarım ve Hayvancılık Bakanlığı, http://www.tarim.gov.tr [Erişim: 10/03/2016].

Anonim. 2016b. İl Gıda Tarım ve Hayvancılık Bakanlığı Faaliyet Raporu, http://corum.tarim.gov.tr/Belgeler/ [Erişim: 10/03/2016].

Aydemir C, Pıçak M. 2007. GAP Bölgesi'nde hayvancılığın gelişimi ve Türkiye içindeki konumu. Elektronik Sosyal Bilimler Dergisi, 6 (22): 13-37

Demir N, Yavuz F. 2010. Hayvancılık Destekleme Politikalarına Çiftçilerin Yaklaşımlarının Bölgelerarası Karşılaştırmalı Analizi, Atatürk Üniversitesi Ziraat Fakültesi Dergisi, 41: 113-121.

Eren E. 2006. Kahramanmaraş ili Göksun ilçesinde sığır besiciliği yapan işletmelerin yapısı ve sorunları. (Yüksek Lisans Tezi), Kahramanmaraş Sütçü İmam Üniversitesi Fen Bilimleri Enstitüsü Tarım Ekonomisi Anabilim Dalı, Kahramanmaraş.

Gündüz O, Dağdeviren M. 2011. Bafra ilçesinde süt maliyetinin belirlenmesi ve üretimi etkileyen faktörlerin fonksiyonel analizi. Yüzüncü Yıl Üniversitesi Tarım Bilimleri Dergisi, 21 (2): 104-111.

Minitab. 2007. Minitab Institute Inc. Meet Minitab 15. ISBN: 978-0925636-51-5. USA.

Özkan U. Erkuş A. 2003. Bayburt ilinde sığır besiciliğine yer veren tarım işletmelerinin ekonomik analizi. Tarım Bilimleri Dergisi, 9 (4): 467-472.

Sapan V, Etiler D. 2004. Türkiye'de Hayvancılık Değerleme Raporu. Tarım ve Köyişleri Bakanlığı, Ankara.

TÍGEM 2013. Tarımsal İşletmeler Genel Müdürlüğü, Hayvanc1l1k Sektör Raporu. Syf:14.

TÜİK 2015. Türkiye İstatistik Kurumu, Veri tabanları, Hayvancılık istatistikleri, https://biruni.tuik.gov.tr/hayvancilikapp/hayvancilik.zul [Erişim: 10/03/2016].

Topçu Y. 2004. Erzurum ili sığır besiciliği işletmelerinde girdi kullanımı ve üretim maliyeti üzerine bir araştırma. Atatürk Üniversitesi Ziraat Fakültesi Dergisi, 35 (1-2): 65-73.

Vural H, Fidan H. 2007. Türkiye'de hayvansal üretim ve hayvancılık işletmelerinin özellikleri. Tarım Ekonomisi Dergisi, 13 (2): 49-59.

Yüzer AF, Ağaoğlu E, Tatlıdil H, Özmen A, Sıklar E. 2006. İstatistik, Anadolu Üniversitesi Yayını No: 1448, Açıöğretim Fakültesi Yayını No: 771, ISBN: 975-06-01831, Eskişehir. 